\title{
Community-development programs and the implications for women migrant workers' pre-departure preparation in Eastern Indonesia
}

\author{
Yakob Metboki *, Jollyanes Petrecia Hosang Ledo \\ Faculty of Teacher and Educational Sciences, Universitas Kristen Artha Wacana. \\ Jalan Adi Sucipto No. 147, Oesapa, Kupang, Indonesia \\ * Corresponding Author. yakobmetboki@yahoo.com \\ Received: 13 October 2019; Revised: 27 December 2019; Accepted: 27 February 2020
}

\begin{abstract}
This paper aims to describe the implementation of the community development programs and the benefits originated from the prospective women migrant workers' responses after taking the trainings. The problems are "What are community development programs for prospective women migrant workers during pre-departure preparation? and, "What are the benefits originated from participants' responses on implemented programs? The present study applies descriptive qualitative method, where data collection techniques utilized needs analysis and surveys. Data analysis comprises data collection, data presentation, data interpretation and conclusions. Total participants are 41 prospective maids. The results reveal that the implementation of community development programs has significant implications for prospective women migrant workers' pre-departure preparation before leaving for the receiving countries. Having participated the programs, the participants disclose the benefits they gain from each acting program. First, Basic English teaching benefited them to use English according to work needs. Second, the character-building program has nurtured them with life skills and selfunderstanding of the importance of being whole persons to provide good services. Last, they do not simply experience trainings but also complete concrete tasks through work skills training. Overall, the implementation of the community development programs in this study promotes significant impact to prospective Indonesian women migrant maids' pre-departure preparation. Keywords: migrant workers, community development, training, benefit

How to Cite: Metboki, Y., \& Ledo, J. (2019). Community-development programs and the implications for women migrant workers' pre-departure preparation in eastern Indonesia. JPPM (Jurnal Pendidikan dan Pemberdayaan Masyarakat), 6(2), 170-179. doi:https://doi.org/10.21831/jppm.v6i2.27622
\end{abstract}

do:

https://doi.org/10.21831/jppm.v6i2.27622

\section{INTRODUCTION}

Seeking for better life overseas is the dream for most migrant people. It is poverty, the acute condition, that boosts people migrate to any receiving countries (Rosenberg, 2003), and so, they will take whichever gate they like to leave for a work overseas. In Asia, the domestic migration has scored a tremendous movement with the increase of 1.5 million to 6.9 million in between 1990 and 2015 (International Labour Organization, 2018, p. xiii). Indonesia, one of the ASEAN group initiators, has been referred to as one of the Southeast Asia's countries to send its large number of people to work overseas (Hugo, 2006; International Organization for
Migration, 2010; M. Rahman, 2011). No matter how much money can they make, they simply puts their trust on a predetermined job, which can change it into monthly salary. The phenomenon is referred to as people mobility from their local entities (Kaufmann et al., 2004; Kofman, 2004).

Moving forward to seek for issues hindering the massive migration of domestic workers among Asian countries, one may find out another innovative migration trend that sets up a changing paradigm in the sense of gender (Ionesco \& Aghazarm, 2009; Kelly, 2011; Kofman, 2004; Laczko \& Aghazarm, 2009; Lan, 2008). Piper (2005) mentions gender in migration as situations where women, 
JPPM (Jurnal Pendidikan dan Pemberdayaan Masyarakat), 6 (2), 2019 - 171

Yakob Metboki, Jollyanes Petrecia Hosang Ledo

other than men, have opportunity to answer the increasing demand of the global labour market. Globally, the number of women marks an increasing feature of migration trend (Alda, 2012; UN Women, 2017). It is therefore likely that such a high number of women from most Asian countries who decided to leave their families (Navallo, 2016). Indonesia sets out 76 percent women out of total number of migrant workers in 2012 (International Labour Organization, 2018). Unfortunately, 90 per cent of them are domestic workers with lacking of skills, and so, having fewer job options.

In 2007, the Indonesian government established the National Agency for Placement and Protection of Indonesian Overseas Workers (BNP2TKI), which stands for both protecting as well as advancing the Indonesian workers in the overseas job market (M. Rahman, 2011). Following move, a dramatic increase of domestic job seekers shows a positive trend across provinces of the archipelagic country. The number of people, especially, from the East Nusa Tenggara ranges in around the first ten-pole position in every timeframe. In 2011, ILO released it on the fifth position. Then, there is a falling and raising fluctuation shows another interesting trend around the top ten range before 2017 (BBC News Indonesia, 2017; A. Rahman et al., 2014). The fluctuation indicates that the flow of overseas migrant workers from East Nusa Tenggara is relatively steady. Despite their protection and management, they suffer from several major drawbacks. The Board of Placement and Protection Services for Indonesian Workers (BPPTKI) released 32 victims of migrant workers originated from NTT between January and May 2018 (Viana, 2018). Nationally, the government proclaims that solutions for problems hindering migrant workers are real. In this sense, the Foreign Minister of Indonesia has claimed to break down the number of cases up to 84 per cent in 2018. Compared to the previous year, it is indicated to be twenty percent higher than the previous year. Turning back to note from the biggest number of victims from NTT in the same year, it is presumed that there is still little attention from the Indonesian govern- ment on ways to cope with all protection aspects (Anya, 2018).

Many analysts argue that most strategies for pre-departure preparation brought little implications. (Allen, 2016) argues that the ineligibility of the prospective migrant workers tends to result a mismatch between training job in home country and that of receiving job from employer overseas. More, Allen exemplifies that jobs related to production and agriculture tends to refer to those of low education level. It is, now, becoming an ever-present need to manage good migration processes starting from predeparture preparation, education and trainings that meets to target employers' needs (Rider \& Klaeysen, 2015; Tewari \& Sharma, 2010), and so, there should be integration among different sectors that boost the spirit of developing strategies on the plane of quality framework (Allen, 2016). With different roles and initiatives, there must be foundations and partnership building that hinders protection for migrant workers (Asis \& Agunias, 2012). In the Philippines, for example, the NGOs played much of their supporting strategies for the migrant workers empowerment. This working strategy is believed to drive working capacities over prospective migrant workers before leaving for each of the receiving countries.

Generally speaking, most Indonesian migrant workers are weak in foreign language ability. The World Bank, even, claims them to be lacking of English (Hamdi, 2016). It is, now more alarming that the inclusion of local institutions with practical English teaching should have been an alternative strategy to promote them practical English learning experience (Asis \& Agunias, 2012). Theoretically speaking, they are the ones who leave their families, they afford for being familiar with new culture, in so doing, they need such a participatory approach, which directs their orientation towards learning experiences (Auerbach et al., 1996; Isknadar et al., 2019; Johns \& Price-Machado, 2001). In this sense, teachers should be familiar with who they are and what sort of existing potentials they have for learning (Weinstein, 2001).

Another issue to figure out is to answer the employers' demand. The reason is rooted 
on the fact that not simply skills and/or competences the migrant workers would, but also characters, which display their ethical strength (International Organization for Migration, 2010; Lindblad, 2017). While most Indonesian overseas workers are originated from different urban areas, capacity-building programs for awareness-raising program would strengthen their self-confidence to encounter culture shock, stress, loneliness and professional issues (Sijapati, 2016). On top of that, any education programs should bring into account the description of character qualities that show them what and how they could emerge themselves in new atmosphere. In International Organization for Migration (2010) in its Indonesian Labour Migration report emphasizes the need of good training as well as empowerment and character building for raising self-regulated understanding in the market place. More presently, the (UN Women, 2019) flagship report highlights that a major change for protecting Indonesian overseas workers must be best practiced from local context. One of the alternative strategies is empowering the community (Hartadi et al., 2019). What it meant from this notion is the empowerment of the community center that is in charge of preparing the prospective women migrant workers. This study, therefore, aims to elucidate the narrative events of the community development programs in helping the training center for preparing the workers and to give an account of the benefits originated from their responses after completing each program.

\section{METHOD}

To date there has been implications of the empowerment program women migrant workers; this study utilizes qualitative approach to collect the data (Stake, 2010). The participants of the present study consist of 41 women originated from different regencies in East Nusa Tenggara Province-Indonesia. They were trained at an official training center in Kupang, the capital city of the province.

Data were gathered from multiple sources at various time points during March to July 2019. The initial data was taken from needs analysis on each program. It aims to gain background information from the parti- cipants to plan the programs. Content of needs analysis adapts Rahman's format (M. Rahman, 2011). The results were, then, figured out in the form of charts. The following data was from survey, taken after the participants completing each program. It was formulated in Bahasa Indonesia (Indonesia language), where the participants address their responses due to posed questions. Extracts of sample responses appeared on findings are translated into English. Data from both needs analysis and surveys were comprehensively interpreted and discussed using descriptive qualitative analysis.

\section{RESULT AND DISCUSSION}

\section{Result}

The Community Development Program comprises two soft skill education, namely Basic English Teaching and Character Building. The other one - hard skill program applies work skill training.

First, Soft skill education

Soft skill education comprises Basic English and Character Building.

Basic English Teaching

Basic English Teaching was started from March to May 2019, with twelve meetings in total. Time allotment for each meeting is one and a half hour. The instructor was from English Eeducation Study Program of AWCU Kupang. Initially, there was needs analysis, which aimed to obtain background information that grounds the organizations of the program. Its results show that ninetynine per cent of the total candidates have not taken any English course or the like before. Next, the participants' aims for taking Basic English are vary. Most surveyed participants want to be able to perceive what their employers mean. A-one-four of them want to understand and use it as a means of daily communication. While a very few ones are willing to know about how English is different in terms of reading, writing, listening and speaking. Basic English Teaching program was, then, planned accordingly.

The materials consist of introducing self, showing direction and positions, describing things, shopping, expressing num- 
JPPM (Jurnal Pendidikan dan Pemberdayaan Masyarakat), 6 (2), 2019 - 173

Yakob Metboki, Jollyanes Petrecia Hosang Ledo

bers, talking on the telephone and practice cooking instructions. Besides, there are several possible explanations for the finding that the instructor applied three integrated methods, namely Grammar Translation Method (GTM), Total Physical Response (TPR) and Communicative language Teaching (CLT) (Larsen-Freeman, 2000). Most frequently, teaching and learning application run through translation tasks and exercise for understanding meanings of vocabularies, phrases and sentences. In certain way, the instructor described the context of the three notions, while the participants guess and write down meanings. As the participants are about to get confused with the description, the instructor, then, demonstrated the way they work in action. In this sense, her frequent use of English in the classroom promotes an atmosphere of the target language in the classroom. In so doing, the participants are unconsciously forcing themselves to get involved in making meaningful context of English accordingly.

Furthermore, classroom teaching and learning always began with fifteen minutes review of previous lessons. This strategy engaged the participants in competition to recall the materials. The most interesting finding was on recalling meanings of vocabularies and phrases. Now, as far as the process of instruction is concerned, the instructor's attention spread determined roles that the participants must play due to her instructions. It is interesting to note that in all teaching practices of Basic English, there was modeling, not only the instructor, but also the participants. To be more precise, the instructor welcomed one or two former women migrant workers to be models for others. Moreover, teaching and learning was also undertaking reasoning skill. For example, after watching a video of making a cup of tea, the participants must propose the reasons why the mug must be warmed first. This activity permitted the participants to negotiate their assumptions. Correspondingly, multiple strategies and/or techniques were applied due context of teaching and learning.

The integration of different methods is realized by the shifting of multiple techniques. Basic English Teaching promotes the integration of three underlying methods, i.e.: GTM, TPR and CLT. The instructor has heightened the need of teaching grammar in their ESL instruction. This pattern of classroom teaching and learning processes confirms idea that the application of GTM promotes the instructor to initiate students to negotiate meaning and functions through interactive-based instruction. CLT, on the other hand, sets up teacher's role to be simply as a facilitator and/or communicator for target learners to interact with one another.

Participants' Responses on Basic English Teaching

After taking Basic English program, the participants are given a survey, which covers twelve parameters, i.e.: (1) Suitability of Basic English Teaching and needs, (2) Suitability of materials and needs, (3) Media Used, (4) Time allotment and management, (5) Classroom rules, rapport and disciplines, (6) Instructor's competence, (7) Instructor's comment to participants' task or work, (8) Instructor's feedback to participants, (9) Appropriateness of methods and lessons, (10) Instructor's motivation to participants, (11) Participants' participations, and (12) Evaluation.

Thirty-two individuals out of 40 participants returned the survey. The results are figured out in Figure 1.

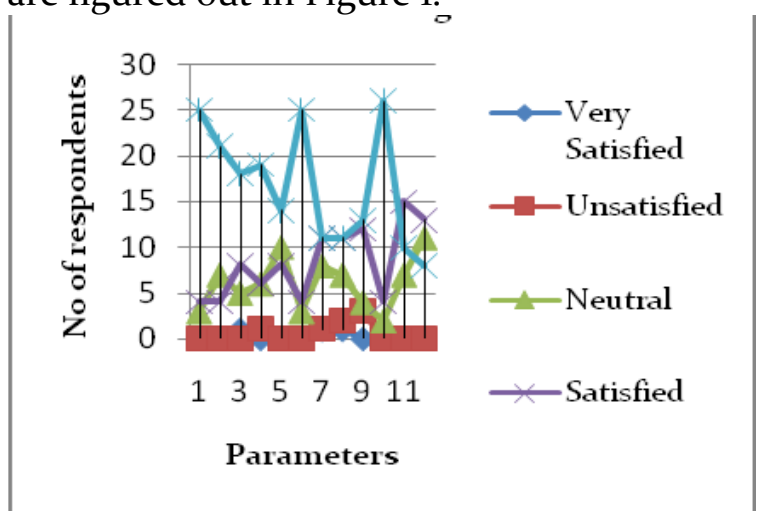

Figure 1. Response on Basic English Teaching

The Figure 1 shows that most participants felt very satisfied with the program. The fluctuation indicates that the peak of the three parameters (1, 6 and 10) must bring impact to the increasing of the other ones. On the other hand, the merit of the lines on parameter seven to nine as well as eleven to 


\section{JPPM (Jurnal Pendidikan dan Pemberdayaan Masyarakat), 6 (2), 2019 - 174 \\ Yakob Metboki, Jollyanes Petrecia Hosang Ledo}

twelve must be taken into account. The underlying reason is the fact that these parameters are dealing with pedagogical substances.

Furthermore, the participants are given task to self evaluate their present English ability, which comprises the ability of speaking skill, listening skill, reading skill and writing skill. Five parameters underline their responses, i.e.: Very disagree (1), Disagree (2), Neutral (3), Agree (4), Very agree (5).

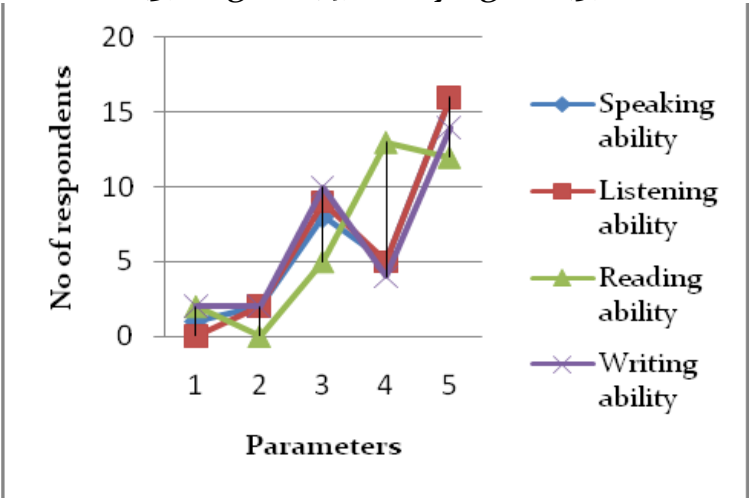

Figure 2. Self-evaluation on Language Skill

The result shown in Figure 2 demonstrates that most participants seemed very agree that there is an increase of the four skills. The trend indicates that the helping programs must be continued in more sustainable system.

Participants' Responses on Basic English Teaching

The following are extracts of comprehensive description from the participants' responses to four open questions, i.e.:

What sort of thing do you like from this program?

The participants preferred the medium of instruction, the delivery, and the explanation that make them enjoy the Basic English learning (YAK). More, they also found that the useful materials are suitable for working in the receiving country (VR). Besides, they love the instructor's guidance, especially when helping them to understand the vocabulary meanings. (RRT). This works as they claimed to be able to construct sentences, translating sentences and addressing question as well as answer (MAH). Last, the participants give much appreciation for the instructor following the task from instructor at all end of the meetings that they are able to recall previous lesson (YKL).

What do you think the instructor should change in this program?

What the instructor should change is on the speed of English (language) speaking, particularly, when speaking. Once the instructor speaks very fast, the participants must be missing the designated points (YKL). Another pivotal issue to be enhanced rests on the process of teaching (VR).

What is your expectation after taking this program?

Having ability to speak in English is their intended expectation (RRT). More interestingly, they wish they would be to apply all the materials on job YKL, VR).

What do you need from further Basic English Teaching?

Due to this question, the participants need extra process of English learning (VR). More practically, they need vocabulary learning and, so does, reading and writing exercises in English (S).

Overall responses indicate that the participants have much concern in the implementation of Basic English teaching, the strategies, the materials and tasks. Their self-awareness in the importance of English, the target language learning, also increased following meaning and function-based learning activities. Having their responses, further planning of program as such should be managed in practical strategies with much focus on micro skills as well.

\section{Character Building}

This helping program began with needs analysis, which addresses two open questions, namely (a) What is your goal to leave for a work overseas? (b) What are your underlying reasons to leave for a work overseas?

The analysis results set out seven parameters over their goal, namely Future, Family, Own household, Earn money, Independent, Success, Self-prestige and happiness.

The Figure 3 out the trend over their goals. What is interesting from the data is on their strong belief that becoming overseas housemaids would change their lives. There- 
fore, simply by earning much money, they will be more independent and success, and, of course, be more responsible for their families at homes.

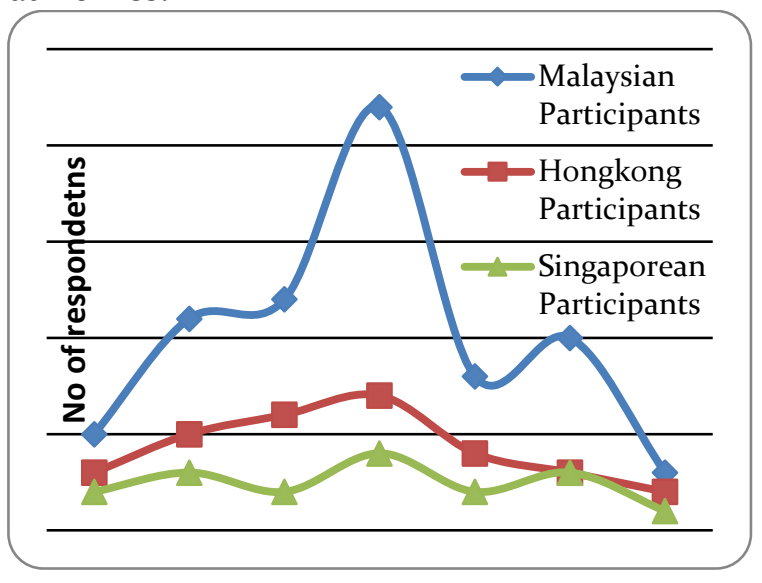

Figure 3. Participants' goals

Having these needs analysis results, the character building was, then, planned accordingly. This program ran for five meetings with the same time allotment from the prior program. The materials cover self-understanding, communication skills and problem solving. The materials are selected and packaged in such a way that there is room for discussion, simulation and modeling. In order to make up their characters and behaviors, the activities are interactive and manipulated using games, simulation and/or demonstration. Generally, the instructor guides the participants to shape themselves as models in performing character values in the practice of life.

Participants' responses on character building

Results of the participants' responses are figured out in Figure 4.

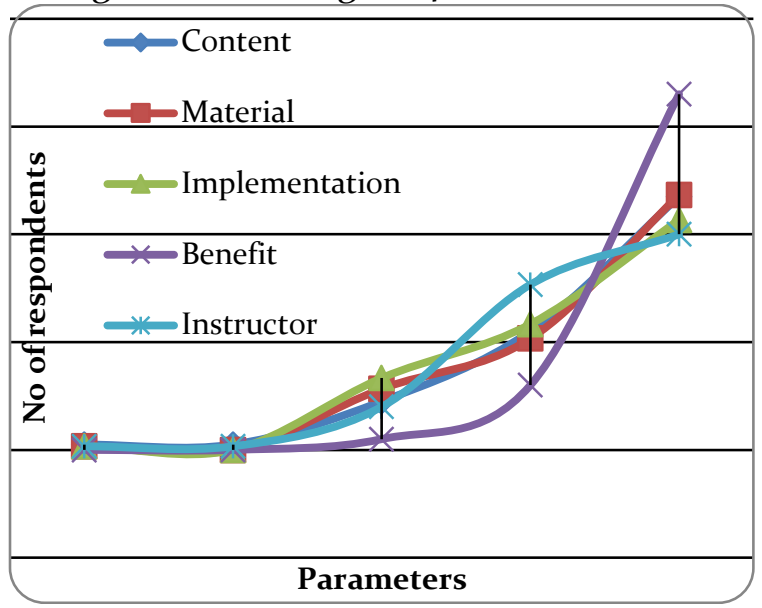

Figure 4. Responses on Character Building
This Figure 4 shows that the distribution of responses on each indicator and the moving trend needs a comprehensive interpretation. In fact, the dissemination of the data rapidly increases; however, in certain positions, the direction of their trend set aside two elements, i.e.: benefits of the program and instructor. On the other hand, the content, material and implementation remained concentrated. Taken together, these trends suggest that the participants found it benefit when the instructor encapsulated the content and material in the applicative implementation.

\section{Participants' Written Responses on Character Building}

The following sections highlight four underlying open questions with the participants' answers. They are as follows:

What sort of thing do you like from this program?

The participants are benefit from the second program because it enables them to evaluate one's character through communication (LRT). More, their understanding on every single weighting accounts much for motivating their life (AM). Next, fun games and sharing on tasks in accordance with materials are introduced grounded knowledge that reflects their goal of working overseas (AL, NT).

What sort of thing should be enhanced in this program?

There are three underlying needs originated from their responses, namely the need of extra range of time for deep learning $(\mathrm{AL})$; the need of paradigm change before welcoming new views (EML); and, the need of deep materials (EKH).

What is your impression of this program?

The participants are very impressed of the program because it changes their personal character to be better. (AST, AL, SPL). More, they committed themselves to apply the knowledge to be their habit $(\mathrm{KH})$.

What is your suggestion for next session of character building?

There should be improvement on the materials and strategy (AL). Additionally, 


\section{JPPM (Jurnal Pendidikan dan Pemberdayaan Masyarakat), 6 (2), 2019 - 176 \\ Yakob Metboki, Jollyanes Petrecia Hosang Ledo}

they expect that the upcoming session would ease their egoism (AST).

The majority of respondents felt that the character building inspires them to be good people through self-understanding regarding the job they will take overseas. They overall suggestion for further session falls on the material development as well as strategies for shaping more personal behaviors.

Second, Hard Skill Education

This helping program was began with needs analysis, which addresses two similar open questions. Firstly, to know their geographical origin and education qualifications. Secondly, to know about their previous job experience. Thirdly, to know about types of job training that the prospective migrant need to take.

Surprisingly, the results proved that upper than 8 o per cent of the participants are from rural areas. With low levels of education and lacking of job experiences, they opt to leave for being migrant workers overseas.

Next, it is clear that most participants (87 \%) had never taken any job training previously. Next, they proposed to know about how to make some foreign meals, cakes and juice (23\%).

Based on the underlying facts, the program team planned to serve three intensive job trainings, namely General Duties and Rules for Housemaid, Making Fruit Pie and Making Fruit Salad.

Implementation of work skill training

Prior to begin each training, the trainers induced the participants into two activities, i.e.: presentation on materials and steps; followed by question and answer to unlock the participants' prior knowledge and/or experiences on focus training. Leading to the training, all the participants are involved in every single training section. The trainers with their expertise managed to elaborate the participants into partial tasks in advance. Then, they are grouped according to steps and/or making process. Here, each group teamed up with the trainer to model them the assigned step and/or process.

Participants' responses on work skill training
Having participated the trainings, the participants gave their responses through survey with five underlying parameters, i.e.: Content, Material, Implementation, Benefit, and Trainer. Their responses on these parameters are represented by the five indicators, i.e.: not very good (1), not good (2), neutral (3), good (4), very good (5).

The results obtained from the survey of work skills training are shown in Figure 5.

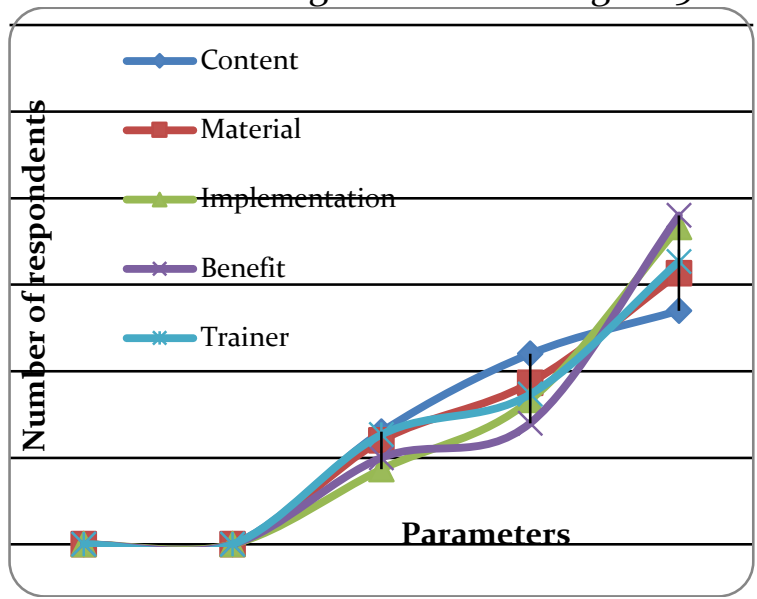

Figure 5. Responses on Work skills training

The Figure 5 shows that good training content delivered by the professional trainers promotes learning and practical experience for the participants.

Participants' Written Responses on Work Skill Training

In this section, the participants are given task to write their personal responses on the training. The questions completed with answer are extracted below.

What sort of thing do you like from this program?

It seems clear that the participants give much appreciation to the program team because it brings about real work trainings, where they could experience for the first time about the procedures, the making processes of food and cakes complete with knowledge the recipes (MAH, MET). The love and proud of all the trainings.

What sort of thing should be enhanced in this program?

All the participants need more trainings on new practices of making meals and cakes. Having all these practices, they 
JPPM (Jurnal Pendidikan dan Pemberdayaan Masyarakat), 6 (2), 2019 - 177

Yakob Metboki, Jollyanes Petrecia Hosang Ledo

would gain more knowledge on more recipes (MAH).

What is your impression of this program?

The participants are impressed of the guidance and practices from the trainers. It makes them able to know the steps in the good way (MET).

What is your suggestion for next session of work skill training?

They express their heart full responses for the instructor to help them preparing more food for foreign people. More additionally, they need to know more kitchen appliances and their use (MET).

The majority of respondents felt that all the trainings were their first experience. What they need for further training is to provide them with more recipes and training on more cooking instructions. Besides, they expect that there is an introduction of new appliances.

\section{Discussions}

This study set out with the aim of elucidating the community development programs and giving an account of women migrant workers' responses over their participation.

Initially, Basic English program has important implications for developing the participants' English (language) ability, particularly the fourth macro language (English) skills. To supporting these, the responses and self-evaluation from participants have proved they are very encouraged to learn English.

Turning now to the Character Building, the participants benefited the content, materials and implementation from the instructor. To put it another way, the participants not solely need an instructor for guiding and counseling; yet, the one to whom they could shape values of character as noted from their responses. Last, it is interesting to note that the implementation of job training demonstrates significant implications for the participants' pre-departure preparations for working overseas as displayed on the charts and the responses.

The most striking result to emerge from these results is rooted on the fact that the implementation of the three helping-community program activities shapes the partici- pants' orientation during pre-departure preparation.

More practically, it brings significant impacts to the training center's pre-departure program in the mainstream program for empowering Indonesian women migrant workers from East Nusa Tenggara of Indonesia. Having these Eastern Indonesian prospective women migrant workers with high motivation to leave for work abroad, these helping programs is believed to boost their commitment to give best services in receiving countries. Based on the recommendations from International Organization for Migration (2010), each party has not only right to seek for the increasing trend of their migration, but also way they could take to bring impact to their social relationships. Then, further work is required to establish this community development program as an alternative approach to empower the local training center (s) to help preparing every single Indonesian prospective women migrant worker to leave for work overseas.

\section{CONCLUSION}

This paper has given an account of and the descriptions for the implementation of the three implemented community development programs for the community partner and the benefits that the participants gain from. Returning to aims posed at the beginning of this study, it is now possible to state from their responses that the programs has made up a new paradigm to create such a sustainable condition that well prescribes predetermined qualifications on the profile of each individual domestic woman migrant worker to be. More, their responses are also becoming grounded information that enables different parties to paraphrase their roles in managing the migration process in more advance atmosphere. The strategies used for these initiative programs may be applied to other training centers elsewhere, particularly, in Indonesia.

Taken together, these findings support strong recommendation to the government of Indonesia to put into commitment that answers the prospective migrant maids' needs through more alternative programs for professional pre-departure preparations. 
JPPM (Jurnal Pendidikan dan Pemberdayaan Masyarakat), 6 (2), 2019 - 178

Yakob Metboki, Jollyanes Petrecia Hosang Ledo

\section{REFERENCES}

Alda, A. K. (2012). Women, migration, and development: The case of domestic workers, sex workers, and migrant wives in Southeast Asia. University of the Basque Country.

Allen, E. R. (2016). Analysis of trends and challenges in the Indonesian labor market. In $A D B$ Papers on Indonesia (16).

Anya, A. (2018). Another year passes with migrant worker issue still in dire straits. The Jakarta Post. https://www.thejakartapost.com/news /2018/12/28/another-year-passes-withmigrant-worker-issue-still-in-direstraits.html

Asis, M. M. B., \& Agunias, D. R. (2012). Strengthening pre-departure orientation programs in Indonesia, Nepal, and the Philippines. Issue in Brief, 5, 1-11.

Auerbach, E., Barahona, B., Midy, J., Vaquerano, F., \& Zambrano, A. (1996). Adult ESL/literacy from the community-to the community: A guidebook for participatory literacy training. Routledge.

BBC News Indonesia. (2017). Puluhan peti mati berisi jasad TKI dikirim ke NTT sepanjang 2016. BBC News Indonesia. https://www.bbc.com/indonesia/indo nesia-38647064

Hamdi, I. (2016). English remains a problem for Indonesian workers, World Bank. TEMPO.CO.

https://en.tempo.co/read/768164/engli sh-remains-a-problem-for-indonesianworkers-world-bank

Hartadi, S., Fakhruddin, F., \& Utsman, U. (2019). The empowerment strategy for prostitutes through competency-based culinary skills training at Semarang Rehabilitation Center. JPPM (Jurnal Pendidikan Dan Pemberdayaan Masyarakat), 6(1), 11-23. https://doi.org/10.21831/jppm.v6i1.2369 7

Hugo, G. (2006). Temporary migration and the labour market in Australia. Australian Geographer, 37(2), 211-231. https://doi.org/10.108o/0004918060o67 2359

International Labour Organization. (2018). Social protection for migrant workers in ASEAN: Developments, challenges, and prospects.

https://www.ilo.org/asia/publications/ WCMS_655176/lang--en/index.htm

International Organization for Migration. (2010). Labour migration from Indonesia: An overview of Indonesian migration to selected destinations in Asia and the Middle East. IOM Jakarta.

Ionesco, D., \& Aghazarm, C. (2009). Gender and labour migration in Asia. International Organization for Migration.

Isknadar, T., Ridlo, A. F., \& Oktaviana, Y. D. (2019). The effect of dumbbell swing exercise method to the arms muscle strength of petanque athletes. 2nd International Conference on Sports Sciences and Health 2018 (2nd ICSSH 2018). https://www.atlantispress.com/proceedings/icssh18/55914054

Johns, A. M., \& Price-Machado, D. (2001). English for specific purposes: Tailoring courses to student needs-and to the outside world. Teaching English as a Second or Foreign Language, 3, 43-54.

Kaufmann, V., Bergman, M. M., \& Joye, D. (2004). Motility: mobility as capital. International Journal of Urban and Regional Research, 28(4), 745-756. https://doi.org/10.1111/j.03091317.2004.00549.X

Kelly, P. F. (2011). Migration, agrarian transition, and rural change in southeast Asia. Critical Asian Studies, 43(4), 479-506. https://doi.org/10.108o/14672715.2011.6 23516

Kofman, E. (2004). Gendered global migrations. International Feminist Journal of Politics, 6(4), 643-665. https://doi.org/10.108o/146167404200o 283408 
JPPM (Jurnal Pendidikan dan Pemberdayaan Masyarakat), 6 (2), 2019 - 179

Yakob Metboki, Jollyanes Petrecia Hosang Ledo

Laczko, F., \& Aghazarm, C. (2009). Migration, environment and climate change: assessing the evidence. International Organization for Migration (IOM).

Lan, P.-C. (2008). New global politics of reproductive labor: Gendered labor and marriage migration. Sociology Compass, 2(6), 1801-1815. https://doi.org/10.1111/j.17519020.2008.00176.x

Larsen-Freeman, D. (2000). Techniques and principles in language teaching. Oxford University.

Lindblad, M. (2017). The importance of character in the workplace. Career Trend.

https://careertrend.com/importancecharacter-workplace-1331.html

Navallo, K. (2016). Asian women and intimate work (edited by Emiko Ochiai and Kaoru Aoyama). Asian Studies: Journal of Critical Perspectives on Asia, 52(2), 142-145.

https://www.asj.upd.edu.ph/mediabox /archive/ASJ_52_2_2016/Navallo_Asian _Women_Intimate_Work_Review.pdf

Piper, N. (2005). Gender and migration: Global Commission on International Migration. Institute for Development Studies, 3, 2012.

Rahman, A., Boboy, J., Banunaek, R., Samid, R. S., Aviero, G., Bernadetha, R., Diaz, Y., Talan, J. P., Robert, J., \& Kiling, I. Y. (2014). Data perdagangan orang Oktober 2014. http://www.irgsc.org/files/Oktober2o1 4FINAL.pdf

Rahman, M. (2011). Gender dimensions of remittances: A study of Indonesian domestic workers in East and Southeast Asia. SSRN Electronic Journal. https://doi.org/10.2139/ssrn.1938306

Rider, L., \& Klaeysen, C. (2015). Employer perspectives on soft skills. 2014 survey report. Washington State Human Resources Council.

Rosenberg, R. (2003). Trafficking of women and children in Indonesia (R. Rosenberg (ed.)). American Center for International Labor Solidarity (Solidarity Center). https://www.solidaritycenter.org/publi cation/trafficking-of-women-andchildren-in-indonesia/

Sijapati, B. (2016). Women's labour migration from Asia and the Pacific: Opportunities and challenges (Working Papers, Issue id:10782). eSocialSciences. https://doi.org/DOI:

Stake, R. E. (2010). Qualitative research: Studying how things work. Guilford Press.

Tewari, R., \& Sharma, D. (2010). Hard skills vs. soft skills: a co-relational study.

UN Women. (2017). Women migrant workers in the ASEAN economic community. UN Women, Asia and Pacific Regional Office.

UN Women. (2019). Gaining protection for Indonesia's migrant workers and their families. UN Women. https://www.unwomen.org/en/news/s tories/2019/6/feature-story-of-changeprotection-for-indonesias-migrantworkers

Viana, G. (2018). Sepanjang Januari-Mei 2018, 32 Orang TKI Asal NTT meninggal dunia di luar negeri. Pos-Kupang.Com. https://kupang.tribunnews.com/2018/ 05/21/sepanjang-januari-mei-2018-32orang-tki-asal-ntt-meninggal-duniadi-luar-negeri

Weinstein, G. (2001). Developing adult literacies. In Teaching English as a second or foreign language (pp. 171-186). Heinle \& Heinle/Thomson Learning Boston, MA. 